\title{
Intercellular Adhesion Molecule-1 Is Upregulated on Peripheral Blood T Lymphocyte Subsets in Dual Asthmatic Responders
}

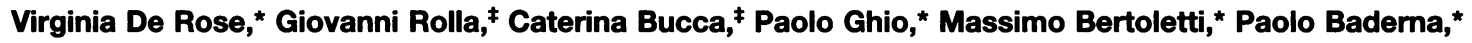 \\ and Emesto Pozzi* \\ *Department of Clinical and Biological Sciences, Respiratory Disease Division, and ${ }^{\ddagger}$ Department of Biomedical Sciences and Human \\ Oncology, University of Turin, Turin 10100, Italy
}

\begin{abstract}
To examine the role of adhesion molecules in $\mathbf{T}$ cell recruitment and activation during allergen-induced late asthmatic response (LAR), we evaluated the expression of lymphocyte function-associated antigen-1 $\alpha$ (LFA-1 $\alpha$ ) and intercellular adhesion molecule-1 (ICAM-1) on peripheral blood T lymphocyte subsets from atopic asthmatic patients and their changes following allergen inhalation challenge. 12 atopic asthmatic patients were studied. Six patients showed only a single early response after allergen challenge, and six developed a dual response. At baseline, dual responders (DR) had a significantly higher expression of ICAM-1 on $\mathrm{CD4}^{+}$ and $\mathrm{CD8}^{+} \mathrm{T}$ lymphocytes as compared with both single early responders $(P<0.005$ and $P<0.02$, respectively) and controls $(P<0.001$, both comparisons). Allergen challenge was followed by a decrease of $\mathrm{CD8}^{+} \mathrm{ICAM}^{+}{ }^{+} \mathrm{T}$ lymphocytes in all DR $(P<0.05)$ and of CD4 ${ }^{+}$ICAM-1 $^{+}$T lymphocytes in four out of six DR, at the time of the LAR. At the same time, a significant rise in serum levels of the soluble form of ICAM-1 was observed in DR. These results suggest that peripheral blood immunoregulatory $T$ lymphocytes are in a higher state of activation in DR as compared with early responders. The upregulation of ICAM-1 on these cells may be important in enhancing airway inflammation in patients with LAR. (J. Clin. Invest. 1994. 94:1840-1845.) Key words: adhesion molecules - lymphocytes • airway inflammation • asthma $\cdot$ allergen.
\end{abstract}

\section{Introduction}

There is increasing evidence that $\mathrm{T}$ lymphocytes play a central role in immune-inflammatory response in asthma. These cells recognize and respond directly to allergens and, through the release of several cytokines, may orchestrate the inflammatory response in asthma (1). T lymphocyte activation has been demonstrated in peripheral blood in both stable and acute severe asthma (2-5) and in bronchoalveolar lavage of patients with mild to moderate disease severity (5-7). Activated $\mathrm{T}$ cells have

Address correspondence to Virginia De Rose, M.D., Clinica di Malattie dell'Apparato Respiratorio, Dipartimento di Scienze Cliniche e Biologiche, Università di Torino, Ospedale S. Luigi Gonzaga, Regione Gonzole 10, 10043 Orbassano (Torino), Italy.

Received for publication 12 April 1994.

J. Clin. Invest.

(C) The American Society for Clinical Investigation, Inc. 0021-9738/94/11/1840/06 \$2.00

Volume 94, November 1994, 1840-1845 also been identified in the bronchial mucosa of atopic asthmatics (8).

A critical initial step in inflammatory cell migration from vascular compartments into the airways is the expression of cell surface adhesion molecules. A large number of these molecules have been identified and characterized in recent years (9-12).

Among $\mathrm{T}$ lymphocyte adhesion receptors, the heterodimer lymphocyte function-associated antigen-1 (LFA-1) ${ }^{1}$ and the intercellular adhesion molecule-1 (ICAM-1) have been shown to play an important role not only in $\mathrm{T}$ cell recruitment, but also in $\mathrm{T}$ cell activation and in the development of specific immune responses $(10,13-16)$. LFA- 1 is a member of the $\beta_{2}$ family of integrins, which is constitutively expressed on most leukocytes (9-14). ICAM-1 is a cell adhesion molecule, belonging to the immunoglobulin supergene family, which is expressed on a variety of hemopoietic and nonhemopoietic cells, and is upregulated at sites of inflammation $(10,17,18)$. ICAM-1 is expressed only weakly on resting $\mathrm{T}$ lymphocytes, but activation of these cells by mitogens or specific cytokines increases its expression (15, 17-19).

Recent studies suggest that the interaction between ICAM1 and LFA-1 plays a role in the development of allergic airway inflammation (20-24).

The allergen-induced late asthmatic response (LAR) may provide a useful model for investigating inflammatory events in atopic asthma. The LAR is associated with airway inflammation and it has been suggested that the recruitment and activation of inflammatory cells lead to local changes in the airways (2528). Recent studies have demonstrated changes in $T$ cell subsets in both peripheral blood and bronchoalveolar lavage after allergen challenge, suggesting a link between $\mathrm{T}$ lymphocyte function and the occurrence of the LAR (29-31).

We speculated that enhanced expression of adhesion molecules on circulating $T$ cells might be relevant to the selective recruitment and activation of these cells.

To test this hypothesis we evaluated the expression of LFA$1 \alpha$ and ICAM- 1 on peripheral blood T cell subsets from atopic asthmatic patients with or without LAR and their changes following allergen inhalation challenge. Normal volunteers were evaluated as controls for baseline data. Moreover, as a soluble form of ICAM-1 has recently been described $(32,33)$ and shown to increase in acute asthma and other inflammatory conditions $(34,35)$, we also determined the serum levels of the soluble form of ICAM-1 (s-ICAM-1) in asthmatic patients and control subjects.

1. Abbreviations used in this paper: DR, dual responder; ER, early single responder; $\mathrm{FEV}_{1}$, forced expiratory volume in $1 \mathrm{~s}$; ICAM-1, intercellular adhesion molecule-1; LAR, late asthmatic response; LFA1, lymphocyte function-associated antigen-1; PE, phycoerythrin; sICAM-1, soluble ICAM-1. 


\section{Methods}

Patients. 12 nonsmoking atopic asthmatic patients $(7$ men and 5 women), 16 to $34 \mathrm{yr}$ of age, were studied. The patients were selected on the basis of $(a)$ positive skin prick tests to common inhalant allergens (Neo Abellò, Ospiate di Bollate, Italy) and increased specific IgE for the relevant allergen; $(b)$ baseline forced expiratory volume in $1 \mathrm{~s}\left(\mathrm{FEV}_{1}\right)$ $>81 \%$ of predicted value (36); (c) increased bronchial responsiveness to inhaled methacholine (i.e., provocative dose required to decrease the FEV 1 by $20 \%$ of its baseline value [ $\mathrm{PD}_{20}$ methacholine] below $800 \mu \mathrm{g}$ ); (d) stable clinical conditions (i.e., no acute asthmatic attack and no respiratory tract infection in the last $2 \mathrm{mo}$ ); $(e)$ no treatment other than rescue $\beta_{2}$-adrenergic drugs, which were discontinued at least $24 \mathrm{~h}$ before the study. All subjects were informed on the nature and the scope of the study and gave written consent.

10 normal volunteers (6 men and 4 women), 24 to $40 \mathrm{yr}$ of age, were evaluated as controls for baseline data. Normal volunteers were asymptomatic, had negative skin prick tests, normal total IgE levels, no detectable serum allergen specific IgE to common aeroallergens, and had normal responsiveness to methacholine. All subjects were nonsmokers.

Allergen inhalation challenge. Spirometry was recorded using a computerized water-sealed spirometer (BAIRES; Biomedin, Padova, Italy). Forced vital capacity and FEV 1 were calculated from the best curve. The allergen inhalation challenge was performed following the guidelines of the American Academy of Allergy (37). For each patient, the allergen producing a positive immediate skin response was chosen for the challenge. Eight patients received grass pollen and four patients received Dermatophagoides pteronyssinus. Allergen solutions were freshly prepared using lyophilized allergens (Neo Abellò) diluted in sterile PBS.

The solutions were delivered by a compressed air nebulizer, controlled by a breath-actuated dosimeter (MEFAR MB3; Markos, Monza, Italy). The dosimeter was set to nebulize for $1 \mathrm{~s}$ (output $10 \pm 0.6 \mu \mathrm{l}$ per $1 \mathrm{~s}$ of nebulization).

After recording baseline spirometry, patients inhaled from the nebulizer five breaths of PBS from functional residual capacity to total lung capacity. $\mathrm{FEV}_{1}$ was recorded $5 \mathrm{~min}$ after the inhalation. Thereafter, they inhaled an initial dilution of 1:10,000 allergen solution (titrated in biological units). $\mathrm{FEV}_{1}$ was recorded $10 \mathrm{~min}$ after each set of inhalations. If $\mathrm{FEV}_{1}$ had not fallen by $20 \%$ from post-PBS value, allergen inhalation was continued with incremental 10-fold concentrations, until a FEV decrease of at least $20 \%$ of the post-PBS value was obtained. The provocation dose required to reduce $\mathrm{FEV}_{1}$ by $20 \%$ of the post-PBS value $\left(\mathrm{PD}_{20}\right.$ allergen) was derived by linear interpolation. $\mathrm{FEV}_{1}$ was measured at 5, 10, 15, 30, 45, and $60 \mathrm{~min}$ after challenge, and then hourly for as long as $10 \mathrm{~h}$. Patients were designated as either single early responders (ER) or dual (early and late) responders (DR) depending on whether they developed a $15 \%$ or greater decrease in FEV $_{1}$ during the 3-10 h period after the initial early-phase reaction. After $10 \mathrm{~h}$ the patients returned home. They were instructed on how to record hourly their peak expiratory flow rate using a portable peak flow meter and what to do in case of respiratory complaints.

Isolation of lymphocytes. Peripheral venous blood was obtained from each subject immediately before allergen challenge (baseline), and at $15 \mathrm{~min}$ and $6 \mathrm{~h}$ after challenge.

Total white blood cell count was determined with an automated cell counter and the differential cell count was determined by examination of Wright-stained slides.

Peripheral blood mononuclear cells were isolated from heparinized venous blood by a standard Ficoll-Hypaque (Pharmacia, Uppsala, Sweden) density gradient technique. The mononuclear cell-rich fraction was collected from the plasma/Ficoll interface and washed twice with RPMI 1640 (GIBCO, Paisley, Scotland). Lymphocytes were then obtained by removal of plastic-adherent cells. Briefly, mononuclear cells were incubated for $1 \mathrm{~h}$ at $37^{\circ} \mathrm{C}$ on plastic petri dishes (Nunc, Roskilde, Denmark); nonadherent cells were then removed, washed again with RPMI 1640 and resuspended in PBS containing $0.1 \%$ sodium azide and $0.5 \%$ BSA (PBS/BSA) for marker analysis.
Table I. Characteristics of the Asthmatic Patients

\begin{tabular}{|c|c|c|}
\hline Parameter & Single responders & Dual responders \\
\hline Number & 6 & 6 \\
\hline Age $(y r)$ & $26.1 \pm 2.81$ & $28.3 \pm 1.59$ \\
\hline $\operatorname{Sex}(M / F)$ & $4 / 2$ & $3 / 3$ \\
\hline Antigen & $\begin{array}{l}\text { 4: Grass pollen } \\
\text { 2: D. pteronyssinus }\end{array}$ & $\begin{array}{l}\text { 4: Grass pollen } \\
\text { 2: D. pteronyssinus }\end{array}$ \\
\hline $\begin{array}{l}{\text { Baseline } \mathrm{FEV}_{1}}^{(\% \text { predicted })}\end{array}$ & $102.3 \pm 5.62$ & $106.6 \pm 1.59$ \\
\hline Early $\mathrm{FEV}_{1}$ ( $\%$ baseline) & $78.72 \pm 1$ & $65.9 \pm 7.5$ \\
\hline Late $\mathrm{FEV}_{1}$ (\% baseline) & $91.4 \pm 1.79$ & $74.9 \pm 4.1$ \\
\hline $\mathrm{PD}_{20}$ methacholine $(\mu g)$ & $171.6 \pm 119.7$ & $147.7 \pm 112.7$ \\
\hline$P_{20}$ allergen & & \\
\hline (biological units) & $0.48 \pm 0.18$ & $0.31 \pm 0.11$ \\
\hline
\end{tabular}

Data are expressed as mean \pm SEM.

Flow cytometry. Adhesion molecule expression on T lymphocyte subsets was determined by flow cytometric analysis after dual labeling with the following murine IgG monoclonal antibodies: anti-CD4 or antiCD8 coupled to phycoerythrin (PE) (Becton-Dickinson, Cowley, UK), anti-LFA-1 $\alpha$ (CD11a) or anti-ICAM-1 (CD54) coupled to FITC (Immunotech, Marseille, France). Negative controls consisted of isotypematched antibodies with irrelevant specificities (Becton-Dickinson) and were used in all experiments.

Aliquots of 500,000 cells in $50 \mu \mathrm{l}$ of PBS/BSA were incubated for 30 min with $10 \mu$ l of one of each of the FITC-labeled antibodies along with $10 \mu \mathrm{l}$ of anti-CD4-PE or anti-CD8-PE. After washing once in PBS/BSA, the cells were resuspended in $1 \%$ paraformaldehyde for analysis. All steps were performed at $4^{\circ} \mathrm{C}$.

Flow cytometry was performed on a FACS Analyzer (Becton-Dickinson). Results were expressed as percent positive cells relative to an isotype control antibody. One aliquot of cells was stained with CD4PE or CD8-PE and CD3-FITC (Becton-Dickinson) to confirm that all CD4 or CD8 cells analyzed were $\mathrm{T}$ lymphocytes.

$s$-ICAM-1 assay. Serum samples from asthmatic patients and control subjects were analyzed for s-ICAM-1 using an ELISA. s-ICAM-1 ELISA kits were purchased from Bender MedSystems (Vienna, Austria). The concentrations of s-ICAM-1 in serum were assayed according to the procedure recommended by the manufacturer. Results were expressed as $\mathrm{ng} / \mathrm{ml}$, relative to a s-ICAM-1 standard.

Statistical analysis. Statistical analysis was performed using nonparametric tests: Mann-Whitney $U$ test for nonpaired data, to compare baseline data in the two groups of asthmatic patients and control subjects; and Wilcoxon's matched pairs test for within-group comparisons. Correlations were determined by the Spearman's rank correlation test. Data are expressed as mean \pm SEM.

\section{Results}

\section{Characteristics of the asthmatic patients}

The clinical characteristics of the asthmatic patients are shown in Table I. A total of six patients showed only a single early asthmatic response after allergen challenge, and six patients developed a dual asthmatic response, within $6 \mathrm{~h}$ from allergen inhalation.

The specific antigen to which the subjects were sensitized was grass pollen, in most of the patients. Only two subjects with single early response and two subjects with dual response were sensitized to $D$. pteronyssinus. Age, baseline lung function, $\mathrm{PD}_{20}$ methacholine, and $\mathrm{PD}_{20}$ allergen were similar in the 
Table II. Absolute Counts and Percentages of $\mathrm{CD}^{+}$and $\mathrm{CD}^{+} \mathrm{T}$ Lymphocytes and CD4/CD8 Ratio in Asthmatic Patients and Control Subjects

\begin{tabular}{cccc}
\hline & \multicolumn{3}{c}{ Markers } \\
\cline { 2 - 4 } Group & CD4* & CD8* & CD4/CD8 \\
\hline Single responders & & & \\
Baseline & $0.94 \pm 0.14$ & $0.46 \pm 0.09$ & \\
& $(45.5 \pm 2.89)$ & $(30.6 \pm 1.91)$ & $1.53 \pm 0.14$ \\
After challenge & & & \\
15 min & $0.92 \pm 0.14$ & $0.51 \pm 0.07$ & \\
& $(48.6 \pm 2.27)$ & $(31 \pm 2.23)$ & $1.61 \pm 0.20$ \\
6 h & $1.07 \pm 0.20$ & $0.56 \pm 0.04$ & \\
& $(48.7 \pm 2.02)$ & $(31.2 \pm 1.75)$ & $1.60 \pm 0.15$ \\
Dual responders & & & \\
Baseline & $0.78 \pm 0.08$ & $0.56 \pm 0.06$ & \\
& $(47.9 \pm 4.1)$ & $(30.6 \pm 2.5)$ & $1.64 \pm 0.23$ \\
After challenge & & & \\
15 min & $0.83 \pm 0.06$ & $0.52 \pm 0.07$ & \\
& $(49.9 \pm 3.58)$ & $(31.7 \pm 2.2)$ & $1.63 \pm 0.22$ \\
6 h & $0.95 \pm 0.14$ & $0.64 \pm 0.10$ & \\
& $(48.5 \pm 3.77)$ & $(29.2 \pm 1.1)$ & $1.68 \pm 0.10$ \\
Controls & & & \\
Baseline & $0.82 \pm 0.11$ & $0.40 \pm 0.08$ & \\
& $(47.3 \pm 1.97)$ & $(29.9 \pm 1.2)$ & $1.61 \pm 0.12$
\end{tabular}

* Absolute counts $\left(\times 10^{-9} / \mathrm{liter}\right)$ and percentages (in parentheses) of peripheral blood $\mathrm{CD}^{+}$and $\mathrm{CD}^{+} \mathrm{T}$ lymphocytes in single responders $(n$ $=6)$, dual responders $(n=6)$, and controls $(n=10)$. Data are expressed as mean $\pm \mathrm{SEM}$.

two groups. Although the early maximum $\mathrm{FEV}_{1}$ fall was larger in DR than in ER, the difference was not statistically significant.

\section{Flow cytometry}

Baseline data. The absolute numbers and the percentages of $\mathrm{CD} 4^{+}$ and $\mathrm{CD}^{+} \mathrm{T}$ lymphocytes as well as the CD4/CD8 ratio did not differ in ER, DR, and control subjects at baseline (Table II).

The analysis of adhesion molecule expression on $\mathrm{T}$ lymphocyte subsets showed that dual asthmatic responders had a significantly higher percentage of $\mathrm{CD}^{+} \mathrm{T}$ lymphocytes expressing ICAM-1 when compared with single early responders $(P<0.005)$ and control subjects $(P<0.001)$; in contrast, no significant differences were observed between the latter two groups (Fig. $1 A$ ). Even if to a lesser extent, the percentage of $\mathrm{CD}^{+} \mathrm{T}$ lymphocytes expressing ICAM-1 was also significantly higher in dual asthmatic responders, compared with single responders $(P<0.02)$ and control subjects $(P<0.001)$. No significant differences were observed between ER and control subjects (Fig. $1 B$ ).

Baseline values of both $\mathrm{CD} 4^{+}$ICAM- $1^{+}$and $\mathrm{CD} 8^{+}$ICAM$1^{+}$subpopulations from the overall asthmatic patients were significantly related to the changes in $\mathrm{FEV}_{1}$ at the time of the LAR ( $r=0.636, P<0.03$ and $r=0.629, P<0.03$, respectively), whereas no correlations were observed with baseline $\mathrm{FEV}_{1}$, $\mathrm{PD}_{20}$ methacholine, or $\mathrm{PD}_{20}$ allergen.

As shown in Table III, no differences were observed in the percentage of $\mathrm{CD}^{+} \mathrm{LFA}-1 \alpha^{+}$or $\mathrm{CD}^{+} \mathrm{LFA}-1 \alpha^{+} \mathrm{T}$ lymphocytes between single early and dual asthmatic responders and between the two groups of patients and control subjects, at baseline ( $P>0.05$, all comparisons).
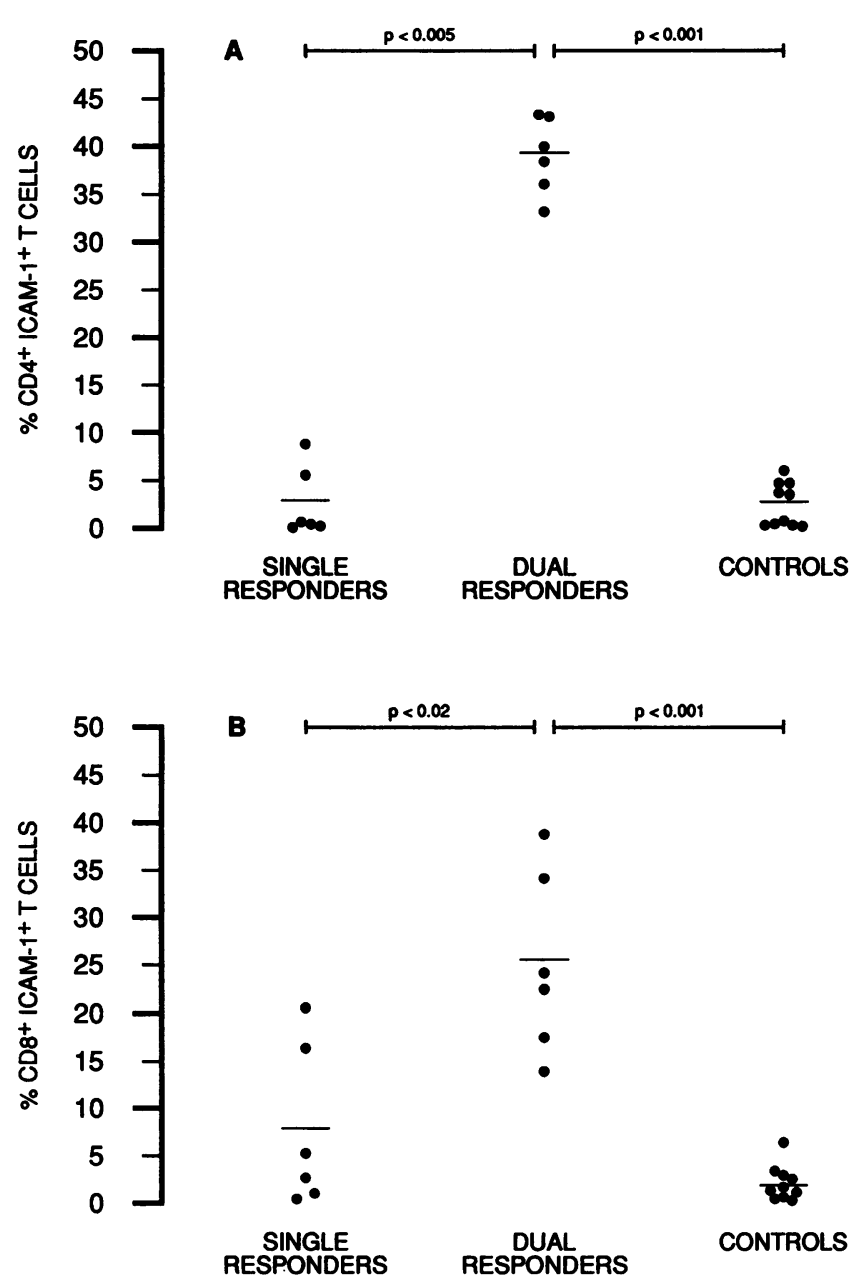

Figure 1. Baseline percentages of peripheral blood CD4 ${ }^{+} \mathrm{ICAM}-1^{+} \mathrm{T}$ lymphocytes $(A)$ and $\mathrm{CD}^{+} \mathrm{ICAM}^{-1^{+}}$T lymphocytes $(B)$ in single asthmatic responders $(n=6)$, dual asthmatic responders $(n=6)$, and control subjects $(n=10)$. Bars represent mean values.

Data after challenge. After allergen challenge, the percentage of $\mathrm{CD}^{+} \mathrm{T}$ lymphocytes expressing ICAM-1 significantly decreased in dual asthmatic responders, at $6 \mathrm{~h}$, compared with baseline values and values at $15 \mathrm{~min}(P<0.05$ for both comparisons) (Fig. 2). However, no correlation was found between changes of $\mathrm{CD}^{+} \mathrm{ICAM}^{+}{ }^{+} \mathrm{T}$ lymphocytes and $\mathrm{FEV}_{1}$ changes at the time of the LAR.

There was a remarkable decrease in the percentage of $\mathrm{CD} 4^{+}$ ICAM-1 ${ }^{+} \mathrm{T}$ lymphocytes in four out of six dual responders at 6 $h$ after challenge. However, the decrease did not reach statistical significance in the overall population of DR. No significant changes in the percentage of $\mathrm{CD}^{+}{ }^{+} \mathrm{ICAM}^{-}{ }^{+}$and $\mathrm{CD} 8^{+}$ICAM$1^{+} \mathrm{T}$ lymphocytes were observed after challenge in patients with single early response (Fig. 2).

The absolute numbers and the percentages of $\mathrm{CD}^{+}$and $\mathrm{CD8}^{+} \mathrm{T}$ lymphocytes as well as the CD4/CD8 ratio did not change, after allergen challenge, either in ER or DR (Table II). Similarly, no changes were observed in the percentage of $\mathrm{CD}^{+}$ or $\mathrm{CD}^{+} \mathrm{T}$ lymphocytes expressing LFA-1 $\alpha$ (Table III).

\section{s-ICAM-1 assay}

Baseline serum levels of s-ICAM-1 were not significantly different between the two groups of asthmatic patients. Similarly, 
Table III. Percentages of $C D 4^{+} L F A-1 \alpha^{+}$and $C D 8^{+} L F A-1 \alpha^{+} T$ Lymphocytes in Asthmatic Patients and Control Subjects

\begin{tabular}{|c|c|c|}
\hline \multirow[b]{2}{*}{ Group } & \multicolumn{2}{|c|}{ Markers } \\
\hline & $\mathrm{CD}^{+}{ }^{+}$LFA- $1 \alpha^{+}$ & $\mathrm{CD}^{+} \mathrm{LFA}^{-1} \alpha^{+}$ \\
\hline \multicolumn{3}{|c|}{ Single responders $(n=6)$} \\
\hline Baseline & $42.6 \pm 3.64$ & $28.97 \pm 1.90$ \\
\hline \multicolumn{3}{|l|}{ After challenge } \\
\hline $15 \mathrm{~min}$ & $47.03 \pm 1.94$ & $29.2 \pm 2.70$ \\
\hline $6 \mathrm{~h}$ & $47.8 \pm 1.50$ & $29.1 \pm 1.23$ \\
\hline \multicolumn{3}{|c|}{ Dual responders $(n=6)$} \\
\hline Baseline & $47.5 \pm 4.00$ & $28.2 \pm 2.19$ \\
\hline \multicolumn{3}{|l|}{ After challenge } \\
\hline $15 \mathrm{~min}$ & $47.1 \pm 3.13$ & $29.7 \pm 2.39$ \\
\hline $6 \mathrm{~h}$ & $48.2 \pm 2.06$ & $27.7 \pm 1.77$ \\
\hline \multicolumn{3}{|l|}{ Controls $(n=10)$} \\
\hline Baseline & $43.9 \pm 2.75$ & $28 \pm 0.90$ \\
\hline
\end{tabular}

Data are expressed as mean \pm SEM.

no differences were observed between either ER and DR and control subjects (ER: $288.68 \pm 28.49 \mathrm{ng} / \mathrm{ml}$, DR: $281.23 \pm 12.88$ $\mathrm{ng} / \mathrm{ml}, \mathrm{C}: 322.37 \pm 21.21 \mathrm{ng} / \mathrm{ml} ; P>0.05$, all comparisons).

After allergen challenge, serum levels of s-ICAM-1 significantly increased in dual asthmatic responders, at $6 \mathrm{~h}$, compared with baseline values and values at $15 \min (P<0.03$ for both comparisons) (Fig. 3).

\section{Discussion}

This study was designed to evaluate the expression of the adhesion molecules LFA- $1 \alpha$ and ICAM- 1 on peripheral blood T lymphocyte subsets from atopic asthmatic patients and their changes after allergen inhalation challenge. The main findings are: (a) dual asthmatic responders, at baseline, had an increased expression of ICAM-1 on $\mathrm{CD}^{+} \mathrm{T}$ lymphocytes and, to a lesser extent, on $\mathrm{CD}^{+} \mathrm{T}$ lymphocytes as compared with both single early responders and control subjects, and $(b)$ allergen challenge was followed by a marked decrease of $\mathrm{CD}^{+} \mathrm{ICAM}-1^{+} \mathrm{T}$ lymphocytes in all DR and of $\mathrm{CD}^{+}$ICAM-1 ${ }^{+} \mathrm{T}$ lymphocytes in four out of six DR at the time of the LAR. At the same time, a significant rise in serum levels of the soluble form of ICAM1 occurred in dual asthmatic responders.

ICAM-1 is a cell adhesion molecule expressed on a variety of hemopoietic and nonhemopoietic cells, and upregulated by inflammatory mediators $(10,15,17-19)$. It is the counterreceptor for the leukocyte integrins LFA-1 and Mac-1 (38-41). The relevance of ICAM-1/LFA-1 interaction in the development of allergic airway inflammation is provided by the observation that anti-ICAM-1 monoclonal antibodies are able to inhibit both inflammatory cell infiltrate and acquired bronchial hyperresponsiveness accompanying repeated allergen challenge in nonhuman primate models (20). Furthermore, in nasal biopsies from patients with perennial allergic rhinitis, ICAM-1 expression on endothelial cells was shown to be significantly increased, compared with healthy controls (23). Upregulation of ICAM-1 has also been observed in human skin $6 \mathrm{~h}$ after local intradermal challenge, in association with tissue eosinophilia (42).

Recent studies have shown that ICAM-1/LFA-1 interaction
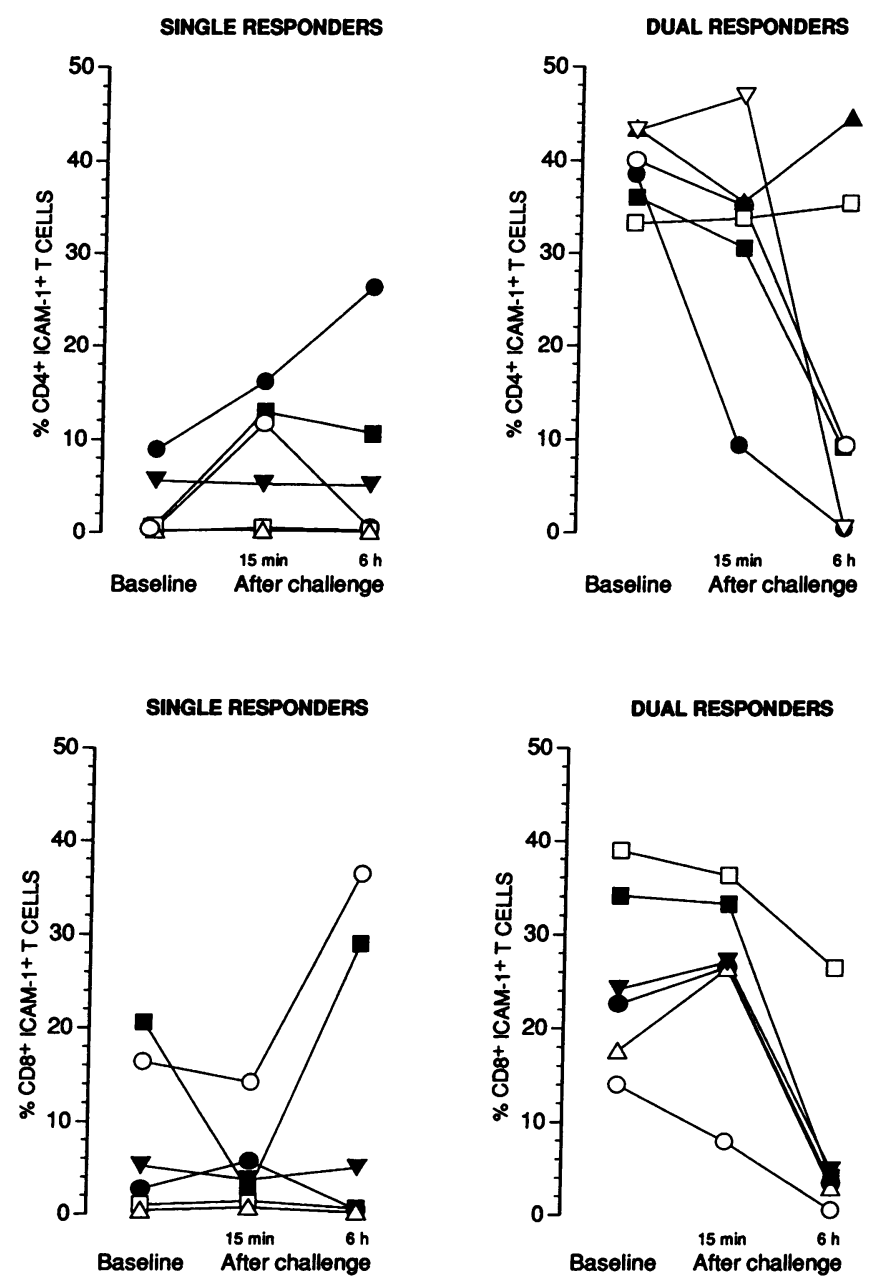

Figure 2. Changes in peripheral blood $\mathrm{CD} 4^{+} \mathrm{ICAM}-1^{+} \mathrm{T}$ lymphocytes (top panels) and $\mathrm{CD}^{+}$ICAM-1 ${ }^{+} \mathrm{T}$ lymphocytes (bottom panels) in single asthmatic responders $(n=6)$ and dual asthmatic responders $(n$ $=6$ ) after allergen inhalation challenge. The percentage of $\mathrm{CD}^{+}$ICAM$1^{+} \mathrm{T}$ lymphocytes significantly decreased, in dual responders, at $6 \mathrm{~h}$ after challenge, compared with baseline values and values at $15 \mathrm{~min} ; P$ $<0.05$ for both comparisons (bottom right panel).

not only is required for cell adhesion and migration, but also plays a key role in the immune response; in fact, these adhesion molecules are involved in leukocyte functions such as antigenspecific recognition by $\mathrm{T}$ lymphocytes, $\mathrm{T}$ lymphocyte activation, and Ig production through T-dependent humoral immune responses $(10,13-16)$.

Under normal conditions, only low levels of ICAM-1 are expressed on peripheral blood mononuclear cells, but its expression is increased upon cell activation.

In this context, our observation that ICAM-1 is upregulated on peripheral blood $\mathrm{T}$ lymphocyte subsets and more markedly on $\mathrm{CD}^{+} \mathrm{T}$ lymphocytes, in dual asthmatic responders, suggests that these cells are in a higher state of activation in DR compared with ER and it might reflect the presence of more sustained inflammatory changes in patients developing LAR. We can safely exclude ICAM-1 upregulation as a feature of atopic status, since in atopic patients with single early response, the expression of ICAM-1 on immunoregulatory T cells was not significantly different from control subjects. The degree of ICAM- 


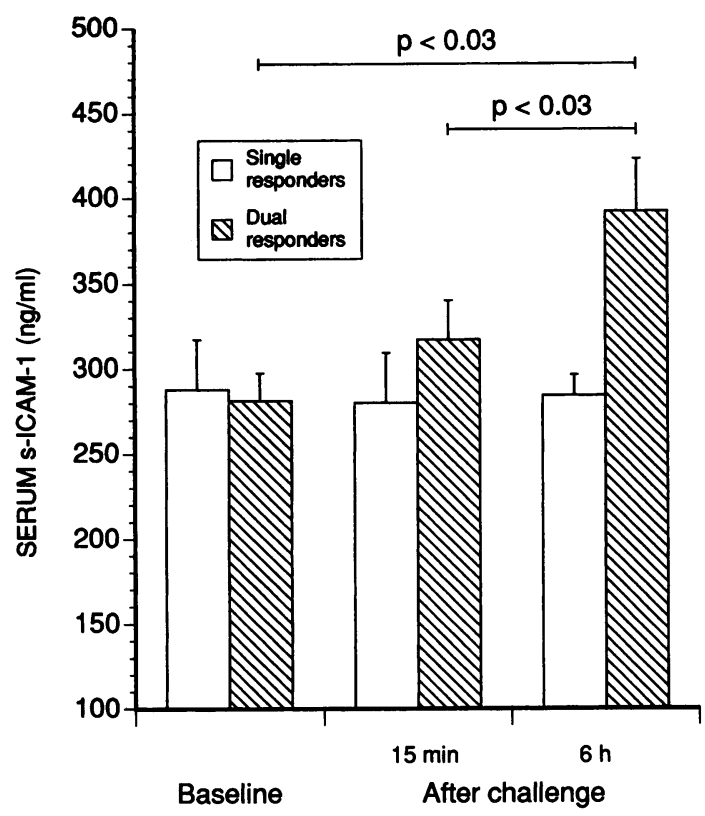

Figure 3. Changes in serum levels of soluble ICAM-1 (s-ICAM-1) in single asthmatic responders $(n=6)$ and dual asthmatic responders $(n$ $=6$ ) after allergen inhalation challenge. Serum levels of s-ICAM-1, expressed as $\mathrm{ng} / \mathrm{ml}$, are on the vertical axis; the time-points studied are on the horizontal axis. Data are expressed as mean \pm SEM. Serum levels of s-ICAM-1 significantly increased, in dual responders, at $6 \mathrm{~h}$ after challenge, compared with baseline values and values at $15 \mathrm{~min} ; P<0.03$ for both comparisons.

1 expression, at baseline, on both $\mathrm{CD}^{+}$and $\mathrm{CD} 8^{+} \mathrm{T}$ lymphocytes from the overall asthmatic population was related to the change in $\mathrm{FEV}_{1}$ at the time of the LAR, suggesting that ICAM1 upregulation on immunoregulatory $T$ cells is related to the occurrence of the LAR. However, further studies including a larger number of patients are needed in order to define whether these changes can predict the occurrence of LAR.

The late phase asthmatic response is associated with airway inflammation (25-27) and is characterized by an inflammatory cell infiltrate in the bronchial mucosa and submucosa (28). The upregulation of ICAM-1 on immunoregulatory T cells in peripheral blood might be the consequence of cytokine release from activated airway inflammatory cells or it might reflect a more prolonged antigenic stimulation in patients with dual asthmatic response. As an alternative explanation, it might be the result of a "spill-over" of activated cells from the airways into vascular compartments. Regardless, the upregulation of ICAM-1 on T cells may play an important role in enhancing and maintaining airway inflammation in patients with LAR. In fact, increased interactions between these cells and antigen-presenting cells or other lymphocytes could lead to chronic inflammation mediated by immunocompetent cell activation and cytokine release.

After allergen challenge, we observed a decrease of $\mathrm{CD}^{+}$ ICAM-1 ${ }^{+} \mathrm{T}$ lymphocytes in all dual asthmatic responders, and of $\mathrm{CD}^{+} \mathrm{ICAM}^{-1^{+}} \mathrm{T}$ lymphocytes in four out of six dual asthmatic responders, at the time of the LAR. The decrease of ICAM-1 expression on T lymphocyte subsets might be the consequence of ICAM-1 shedding from activated cells, as the soluble form of ICAM-1 increases in serum of DR at the time of the LAR. This latter observation is consistent with the results of previous studies showing that atopic patients undergoing segmental bronchoprovocation with antigen have s-ICAM-1 present in bronchoalveolar lavage fluid only during the late response (43). A significant elevation of circulating s-ICAM-1 was also shown in patients with acute asthma when compared to stable asthmatics and control subjects (34). As an alternative explanation, the decrease of $\mathrm{CD}^{+} \mathrm{ICAM}^{+}{ }^{+}$and $\mathrm{CD} 4^{+}$ICAM$1^{+} \mathrm{T}$ lymphocytes at the time of the LAR might reflect the migration of activated $T$ cells from the vascular compartment into the airways; this latter possibility seems less likely since both the numbers and the percentages of $\mathrm{CD}^{+}$and $\mathrm{CD}^{+} \mathrm{T}$ lymphocytes did not change after allergen inhalation challenge. However, as our study was performed only on peripheral blood we cannot exclude the possibility that the decrease of both $\mathrm{CD}^{+}$and $\mathrm{CD}^{+} \mathrm{T}$ lymphocytes expressing ICAM-1 reflects the migration of these cells into the airways.

In this study we did not observe any change in both the absolute number and the percentage of $\mathrm{CD}^{+}$or $\mathrm{CD}^{+} \mathrm{T}$ lymphocytes after allergen challenge in single early and dual asthmatic responders. These results are consistent with those obtained from Frew et al. in sensitized animals challenged with aerosolized ovalbumin (44). Our findings, however, differ from those of Gonzales et al. (30) and of Gerblich et al. (29). The first group of investigators, in fact, found that allergen inhalation by subjects exhibiting a single early response was associated with a significant elevation in the percentage, but not in the absolute number of $\mathrm{CD}^{+} \mathrm{T}$ lymphocytes in the blood. Gerblich et al., in contrast, showed a decrease in peripheral blood CD4 ${ }^{+}$ $\mathrm{T}$ lymphocytes in atopic asthmatic patients after allergen challenge, but none of their patients showed LAR. These discrepancies can probably be explained by the different study design, particularly with respect to $(a)$ the technique of allergen challenge, $(b)$ the different time points studied, and $(c)$ the different disease severity of the population studied.

In conclusion, this study shows that, in dual asthmatic responders, ICAM-1 is upregulated on peripheral blood immunoregulatory $\mathrm{T}$ lymphocytes and particularly on $\mathrm{CD}^{+} \mathrm{T}$ lymphocytes, suggesting that these cells are in a higher state of activation in dual asthmatic responders, compared with single early responders. These results support the concept that more severe inflammatory changes occur in patients with LAR and add further evidence for an important role of adhesion molecules in immune and inflammatory response in asthma.

\section{Acknowledgments}

This work was supported in part by a grant from the Ministero dell'Università e della Ricerca Scientifica (fondi 60\%).

\section{References}

1. Kay, A. B. 1992. "Helper" (CD4 $\left.{ }^{+}\right) \mathrm{T}$ cells and eosinophils in allergy and asthma. Am. Rev. Respir. Dis. 145:S22-S26.

2. Corrigan, C. J., A. Hartnell, and A. B. Kay. 1988. T-lymphocyte activation in acute severe asthma. Lancet. i:1129-1132.

3. Corrigan, C. J., and A. B. Kay. 1990. CD4 T-lymphocyte activation in acute severe asthma: relationship to disease severity and atopic status. Am. Rev. Respir. Dis. 141:970-977.

4. Walker, C., J. C. Virchow, P. L. B. Bruijnzeel, and K. Blaser. 1991. T cell subsets and their soluble products regulate eosinophilia in allergic and nonallergic asthma. J. Immunol. 146:1829-1835.

5. Walker, C., M. K. Kaegi, P. Braun, and K. Blaser. 1991. Activated T cells and eosinophilia in bronchoalveolar lavages from subjects with asthma correlated with disease severity. J. Allergy Clin. Immunol. 88:935-942.

6. Wilson, J. W., R. Djukanovic, P. H. Howarth, and S. T. Holgate. 1992. 
Lymphocyte activation in bronchoalveolar lavage and peripheral blood in atopic asthma. Am. Rev. Respir. Dis. 145:958-960.

7. Robinson, D. S., A. M. Bentley, A. Hartnell, S. R. Durham, and A. B. Kay 1993. Activated memory T helper cells in bronchoalveolar lavage from atopic asthmatics. Relationship to asthma symptoms, lung function and bronchial responsiveness. Thorax. 48:26-32.

8. Azzawi, M., B. Bradley, P. K. Jeffery, A. J. Frew, A. J. Wardlaw, G Knowles, B. Assouf, J. V. Collins, S. Durham, and A. B. Kay. 1990. Identification of activated T lymphocytes and eosinophils in bronchial biopsies in stable atopic asthma. Am. Rev. Respir. Dis. 142:1407-1413.

9. Hynes, R. O. 1987. Integrins, a family of cell surface receptors. Cell. 48:549-555.

10. Springer, T. A. 1990 . Adhesion receptors of the immune system. Nature. (Lond.). 346:425-434.

11. Albelda, S. M., and C. A. Buck. 1990. Integrins and other cell adhesion molecules. FASEB (Fed. Am. Soc. Exp. Biol.) J. 4:2868-2880.

12. Ruoslahti, E. 1991. Integrins. J. Clin. Invest. 87:1-5.

13. Fischer, A., A. Durandy, G. Sterkers, and C. Griscelli. 1986. Role of the LFA-1 molecule in cellular interactions required for antibody production in humans. J. Immunol. 136:3198-3203.

14.Springer, T. A., M. L. Dustin, T. H. Kishimoto, and S. D. Marlin. 1987. The lymphocyte function-associated LFA-1, CD2, and LFA-3 molecules: cell adhesion receptors of the immune system. Annu. Rev. Immunol. 5:223-252.

15. Dougherty, G. J., S. Murdoch, and N. Hogg. 1988. The function of human intercellular adhesion molecule-1 (ICAM-1) in the generation of an immune response. Eur. J. Immunol. 18:35-39.

16. Boyd, A. W., S. O. Wawryk, G. F. Burns, and J. V. Fecondo. 1988. Intercellular adhesion molecule 1 (ICAM-1) has a central role in cell-cell contactmediated immune mechanisms. Proc. Natl. Acad. Sci. USA. 85:3095-3099.

17. Dustin, M. L., R. Rothlein, A. K. Bhan, C. A. Dinarello, and T. A. Springer. 1986. Induction by IL 1 and interferon-gamma, tissue distribution, biochemistry, and function of a natural adherence molecule (ICAM-1). J. Immunol. 137:245-254

18. Dustin, M. L., K. H. Singer, D. T. Tuck, and T. A. Springer. 1988 Adhesion of T lymphoblasts to epidermal keratinocytes is regulated by interferon gamma and is mediated by intercellular adhesion molecule-1 (ICAM-1). J. Exp. Med. 167:1323-1340.

19. Buckle, A. M., and N. Hogg. 1990. Human memory T cells express intercellular adhesion molecule-1 which can be increased by interleukin 2 and interferon-gamma. Eur. J. Immunol. 20:337-341.

20. Wegner, C. D., R. H. Gundel, P. Reilly, N. Haynes, L. G. Letts, and R. Rothlein. 1990. Intercellular adhesion molecule-1 (ICAM-1) in the pathogenesis of asthma. Science (Wash. DC). 247:456-459.

21. Wegner, C. D., R. Rothlein, C. C. Clarke, N. Haynes, C. A. Torcellini, A. M. LaPlante, D. R. Averill, L. G. Letts, and R. H. Gundel. 1991. Inhaled antiICAM-1 reduces antigen-induced airway hyperresponsiveness in monkeys. Am. Rev. Respir. Dis. 143:418a.(Abstr.).

22. Montefort, S., M. Carroll, C. Gratziou, D. O. Haskard, P. H. Howarth, and S. T. Holgate. 1993. Adhesion molecule expression $6 \mathrm{~h}$ after endobronchial allergen challenge in asthmatics. J. Allergy Clin. Immunol. 91:822a.(Abstr.).

23. Montefort, S., I. H. Feather, S. J. Wilson, D. O. Haskard, T. H. Lee, S. T. Holgate, and P. H. Howarth. 1992. The expression of leukocyte-endothelial adhesion molecules is increased in perennial allergic rhinitis. Am. J. Respir. Cell Mol. Biol. 7:393-398.

24. Bentley, A. M., S. R. Durham, D. S. Robinson, G. Menz, C. Storz, O. Cromwel, A. B. Kay, and A. J. Wardlaw. 1993. Expression of endothelial and leukocyte adhesion molecules intercellular adhesion molecule-1, E-selectin, and vascular cell adhesion molecule-1 in the bronchial mucosa in steady-state and allergen-induced asthma. J. Allergy Clin. Immunol. 92:857-868.
25. O'Byrne, P. M., J. Dolovich, and F. E. Hargreave. 1987. Late asthmatic responses. Am. Rev. Respir. Dis. 136:740-751.

26. De Monchy, J. G. R., H. F. Kauffman, P. Venge, G. H. Koeter, H. M. Jansen, H. J. Sluiter, and K. De Vries. 1985. Bronchoalveolar eosinophilia during allergen-induced late asthmatic reactions. Am. Rev. Respir. Dis. 131:373-376.

27. Diaz, P., M. C. Gonzales, F. R. Galleguillos, P. Ancic, O. Cromwell, D. Shepherd, S. R. Durham, G. J. Gleich, and A. B. Kay. 1989. Leucocytes and mediators in bronchoalveolar lavage during allergen-induced late-phase asthmatic reactions. Am. Rev. Respir. Dis. 139:1383-1389.

28. Beasley, R., W. R. Roche, J. A. Roberts, and S. T. Holgate. 1989. Cellular events in bronchi in mild asthma and after bronchial provocation. Am. Rev. Respir. Dis. 139:806-817.

29. Gerblich, A. A., A. E. Campbell, and M. R. Schuyler. 1984. Changes in $\mathrm{T}$-lymphocyte subpopulations after antigenic bronchial provocation in asthmatics. N. Engl. J. Med. 310:1349-1352.

30. Gonzales, C., P. Diaz, F. Galleguillos, P. Ancic, O. Cromwell, and A. B. Kay. 1987. Antigen-induced recruitment of bronchoalveolar helper (OKT4) and suppressor (OKT8) T-cells in asthma. Am. Rev. Respir. Dis. 136:600-604.

31. Gerblich, A. A., H. Salik, and M. R. Schuyler. 1991. Dynamic T-cell changes in peripheral blood and bronchoalveolar lavage after antigen bronchoprovocation in asthmatics. Am. Rev. Respir. Dis. 143:533-537.

32. Seth, R., F. D. Raymond, and M. W. Makgoba. 1991. Circulating ICAM1 isoforms: diagnostic prospects for inflammatory and immune disorders. Lancet. 338:83-84.

33. Rothlein, R., E. A. Mainolf, M. Czajkowski, and S. D. Marlin. 1991. A form of circulating ICAM-1 in human serum. J. Immunol. 147:3788-3793.

34. Lai, C. K., P. Kapahi, D. O. Haskard, P. H. Howarth, S. T. Holgate, and S. Montefort. 1992. Circulating ICAM-1, but not VCAM-1 is increased in the peripheral blood during acute asthma. Eur. Respir. J. 5:399s.(Abstr.).

35. Gearing, A. J. H., and W. Newman. 1993. Circulating adhesion molecules in disease. Immunol. Today. 14:506-512.

36. Quanjer, P. H. 1983. Standardized lung function testing. Bull. Eur. Physiopathol. Respir. 19:1-91.

37. Chai, H., R. S. Farr, L. A. Froelich, D. A. Mathison, J. A. McLean, R. R. Rosenthal, A. L. Sheffer, S. L. Spector, and R. G. Townley. 1975. Standardization of bronchial inhalation challenge procedures. J. Allergy Clin. Immunol. 56:323327.

38. Rothlein, R., M. L. Dustin, S. D. Marlin, and T. A. Springer. 1986. A human intercellular adhesion molecule (ICAM-1) distinct from LFA-1. J. Immunol. 137:1270-1274.

39. Marlin, S. D., and T. A. Springer. 1987. Purified intercellular adhesion molecule-1 (ICAM-1) is a ligand for lymphocyte function-associated antigen 1 (LFA-1). Cell. 51:813-819.

40. Makgoba, M. W., M. E. Sanders, G. E. G. Luce, M. L. Dustin, T. A. Springer, E. A. Clark, P. Mannoni, and S. Shaw. 1988. ICAM-1: definition by multiple antibodies of a ligand for LFA-1 dependent adhesion of B, T and myeloid cell. Nature (Lond.). 331:86-88.

41. Diamond, M. S., D. E. Staunton, A. R. De Fougerolles, S. A. Stacker, J. Garcia-Aguilar, M. L. Hibbs, and T. A. Springer. 1990. ICAM-1 (CD54): a counter-receptor for Mac-1 (CD11b/CD18). J. Cell Biol. 111:3129-3139.

42. Kyan Aung, J., D. O. Haskard, R. N. Poston, M. Thornhill, and T. H. Lee. 1991. ELAM-1 and ICAM-1 mediate the adhesion of eosinophils to endothelial cells "in vitro" and are expressed by endothelium in allergic cutaneous inflammation "in vivo". J. Immunol. 146:521-528.

43. Sedgwick, J. B., S. F. Quan, W. J. Calhoun, N. Jarjour, R. Rothlein, C. D. Wegner, and W. W. Busse. 1992. Expression of ICAM-1 on human peripheral blood and airway eosinophils (EOS) and soluble ICAM-1 (sICAM) in bronchoalveolar lavage fluid (BALF). Am. Rev. Respir. Dis. 145:A188.(Abstr.)

44. Frew, A. J., R. Moqbel, M. Azzawi, A. Hartnell, J. Barkans, P. K. Jeffery, A. B. Kay, R. J. Scheper, J. Varley, M. K. Church, and S. T. Holgate. 1990. T lymphocytes and eosinophils in allergen-induced late asthmatic reactions in the guinea pig. Am. Rev. Respir. Dis. 141:407-413. 